\title{
The Archaeology of Ancient Italy
}

\author{
Charlotte Wikander \& Örjan Wikander
}

\begin{abstract}
The increasing interest of Swedish scholars in the field of Italic and Roman archaeology witnessed in the early 1980's (cf. SA 1981-1985: 185) turned into a decline in the later part of that decade. Here are presented 88 titles by 36 authors $-c .70 \%$ of the figures from the preceding period. We still maintain the stricter attitude to popular articles resorted to then. As a general rule, such articles are to be found here only when directly related to the author's scholarly work.

Charlotte Wikander, Department of Classics, Göteborg University, Västra Hamngatan 3, S-411 17 Göteborg, Sweden.

Örjan Wikander, Department of Classics, Lund University, Sölvegatan 2, S-223 62 Lund, Sweden.
\end{abstract}

\section{COLLECTIONS AND EXHIBITIONS OF ITALIC AND ROMAN ART IN SWEDEN}

\section{Stockholm}

As is normal, the collections of the Medelhavsmuseet dominate the work done during the period on museum collections and exhibitions. Nevertheless, this dominant position has been complemented by the work of A.-M. Leander Touati on the collection of Roman sculpture assembled by King Gustaf III during the late eighteenth century (Leander Touati 1988b, 1990). This was due to two factors: the established position of the scholar in question as one of the few experts on Roman sculpture in Sweden (cf. Section IV.1) and the bicentenary celebration of the National Museum in 1992, which motivated a restoration of the King's original collection in its original environment. A new publication by Leander Touati is forthcoming. During the period covered by this bibliography, this work has yielded preliminary results: a popular account of the collection (1988b) and a detailed study of a head of Commodus, which is demonstrated to be an eighteenth-century falsification (1990).

Publications of the collections of the Medelhavsmuseet continue to appear. The most extensive contribution is that of $\mathrm{Ch}$. Scheffer (1987a): a monograph which publishes the Roman cinerary urns, nine in number, covering the period from the middle of the first century A.C. to $c$. 200. The author illustrates the development of this industry, including an analysis of the decorative schemes. These are interpreted as depending mainly on fashionable trends and workshop preferences rather than religious convictions. The same author (1986a) also published a Roman funerary relief in the collections.

P. Hellström (1989) published a new acquisition: a bronze relief of Late Antique date, tentatively identifying the motif as a Mithraic charioteer. Minor objects (an Etruscan silenus' head, a Roman bronze lamp stand and two fragments of Roman mosaic) are published by Ö. Wikander (1987, 1989c) and M.-L. Winbladh (1988).

The collection of squeezes of Etruscan inscriptions pertaining to O.A. Danielsson 
and his collaborators' work for Corpus Inscriptionum Etruscarum (the collecting ranging from 1885 to 1912 , cf. SA 19811985:186) deposited at the museum in 1981 is further treated by Ö. Wikander (1986b) and Ch. and Ö. Wikander (1987b). These contributions anticipate the forthcoming publication of the collection as addenda to Corpus Inscriptionum Etruscarum II.I.4, dealing with the inscriptions from southern Etruria.

\section{Lund}

The smaller collections of antiquities in Lund have occasioned some contributions: a popular article on Sicilian Silenos-antefixes in the Antikmuseet (Söderlind 1988) and an account of an exhibition of Roman portraits on loan from Ny Carlsberg Glyptotek (Leander Touati 1986). From Kulturen, I. M.B. Wiman published an Etruscan bronze mirror, in connection with her general work on Etruscan mirrors (cf. Section III:3). C. Carlén-Nilsson published a Calenian guttus with relief decoration (1986).

\section{Malmö}

An exhibition of Iron Age and Archaic Etruscan finds from the Soprintendenza alle Antichità dell'Etruria in Florence at the Malmö Konstmuseer in 1987 was the occasion for two popular accounts (Wikander \& Wikander 1987a, Ch. Wikander 1987). The former was a monograph in Swedish describing central features of the Etruscan culture, the latter a short account of the exhibition.

\section{REPORTS ON ARCHAEOLOGICAL FIELD-WORK AND FINDS FROM EXCAVATIONS}

The tendency to abandon of larger excavation projects mentioned in SA 1981-1985 (p. 187 ) has persisted. During the period in question, here work has been mainly concentrated upon the publication of earlier
Swedish excavations (Acquarossa, San Giovenale, Carthage) and individual Swedish contributions to foreign ones (Metaponto, Ostia, Poggio Civitate). The investigation of a Roman villa in Istria (San Simone) and field surveys in Southern Etruria (Acquarossa, Luni) constitute the sole exceptions from the rule.

\section{Acquarossa}

The excavations at Acquarossa, conducted by the Swedish Institute of Classical Studies in Rome in collaboration with the Soprintendenza alle Antichità dell'Etruria Meridionale, were concluded in 1978 (cf. SA 1981-1985:187-189). Apart from the erection of a roof over the remains of the monumental area (Zone F), which involved minor interventions in unexcavated parts of early period layers, field work has been limited to a topographical investigation and survey in the area west and south of the acropolis (E. Rystedt 1990).

In connection with the so-called "Etruscan year" (extended from 1984 to 1986), an exhibition devoted to the Swedish excavations at San Giovenale and Acquarossa was inaugurated at Viterbo. It was introduced by a detailed catalogue, providing a summary of the scholarly results so far achieved (Architettura etrusca nel Viterbese 1986). E. Rystedt describes the topographical setting of the site, C.B. Persson the urbanistic layout. A. Vidén and L. Wendt write about the houses, while the architectural terracottas - a dominant feature among the finds, and thus, in the exhibition as well as the catalogue - are treated by E. Rystedt, M. Strandberg Olofsson, Ch. Wikander and Ö. Wikander. Strandberg Olofsson also presents the monumental area and, together with $\mathrm{Ch}$. Wikander, a historical outline of the site. Pottery and other remains from the "daily life" of the Etruscan town are treated by $\mathrm{Ch}$. Scheffer. Short summaries of the Swedish excavations have been published by $C$. Nylander (1986) and Rystedt et al. (1986a), 
while popular presentations of the Viterbo exhibition are given by E. Rystedt (1986b) and M. Strandberg Olofsson (1986).

Two additional volumes of the final Acquarossa publication have appeared. Ö. Wikander (1986a) published the plain rooftiles (including antefixes and simas), further refining the basic typologies presented in 1972 (cf. SAB 1971-1975:220). The material is presented zone by zone, and the study involves preliminary attempts to assign the finds to specific buildings.

Ch. Wikander (1988a) has concluded her studies of the revetment plaques and other architectural terracottas decorated with white paint on a red ground (cf. SA 19811985:187f.). Besides discussions of the shape of the plaques, their architectural setting and production technique, she makes a thorough examination of the separate, painted motifs as a basis for a tentative dating of a number of well-preserved roofs. Type II plaques, with their varied and unrestrained repertoire of motifs known from late orientalizing pottery (horses, birds, non-figurative decorations, etc.), are to be dated to c. 630-600 B.C., while Type I plaques with Greek-inspired double guilloches and raking simas with lotuspalmette friezes belong in the first quarter of the VI century.

The monumental buildings excavated in Zone $\mathrm{F}$ have been the subject of two recent papers. M. Strandberg Olofsson (1989) gives a summary of the interpretation of the finds presented in her 1984 dissertation (cf. SA 1981-1985;188f.), defending it against a critical review by $M$. Torelli. Ch. \& Ö. Wikander (1990) describe the preliminary results of their work on an earlier, monumental complex, scattered remains of which were discovered below the floor of the later one. Various buildings erected in the last quarter of the VII century B.C. surrounded a triangular courtyard: a lay-out with close affinities to the Regia in Rome and other contemporary buildings. The Etruscan inscription on a bucchero sherd found in the zone confirms the sacred function of the area (Ch. Wikander, Ö. Wikander \& G. Colonna 1987).

Ch. Scheffer (1987c), in the catalogue of an exhibition on Etruscan alimentation, summarizes the results of her earlier studies on cooking and cooking-stands at Acquarossa (cf. SA 1981-1985:188 and 192f.). In another contribution to the same catalogue (1987b), she gives a short outline of our still very restricted knowledge of the Acquarossa diet.

\section{Ficana}

Two cooking-stands from the Scandinavian excavations at Ficana (cf. SA 1981-1985:189) are presented by Ch. Scheffer (1987c), in an exhibition catalogue.

\section{Luni sul Mignone}

A field survery, "La Farnesina project", was initiated in 1987 in the area between Luni sul Mignone and the Tolfa mountains. J. Bengtsson (1989) makes a short presentation of the aim of the project and its first season.

\section{Metaponto}

Swedish participation in the project conducted by the University of Texas at Austin in the countryside north-west of Metaponto (cf. SA 1981-1985:189) continues. Discoveries here form the basis for I.E.M. Edlund's $(1987,1988)$ studies of rural sanctuaries in Etruria and Magna Graecia (cf. below, section III:4). The same author (1986b) also discusses the important finds of IV-II century B.C. kilns for the production of tile, architectural and votive terracottas at $\mathrm{S}$. Angelo Vecchio (cf. SA 1976-1980:101).

M. Prohászka (1986) gives a popular account of her work on iron fibulae discovered in late V-century graves of the Pantanello necropolis.

\section{Ostia}

I. Pohl (1987) published the final results of 
some soundings made by the Soprintendenza Archeologica di Ostia in the western portico of the Piazzale delle Corporazioni (cf. SA 1976-1980:101). Three chronological phases can be discerned before the final organization of the area in the end of the II century A.C. (or later), dated to the reigns of Augustus, Claudius and Hadrianus, respectively.

The most spectacular finds come from the Claudian portico, whose back wall was covered with painted stucco. The decoration was executed in a mixture of the Augustan second style and the third style. Tuscan brick columns were covered by stucco, considerable remains of which were preserved.

\section{Poggio Civitate (Murlo)}

Only two minor Swedish contributions have appeared to the publication of the American excavations at Poggio Civitate (cf. SA 1981-1985:189f.). I.E.M. Edlund-Berry (1989) continues her work in defining a local, "Murlo style". A study of four terracotta heads from the Archaic building (dated 600/575 B.C.) strengthens the author in her belief that a local, sculptural style developed at the site during the century of its existence. Edlund et al. (1989) also contributed to the historiography of the excavations in an obituary of its director, Kyle M. Phillips, Jr.

\section{San Giovenale}

The results of the Swedish excavations at San Giovenale in 1956-1965 (cf. SA 19811985:190-192) were summarized in the catalogue of the 1986 Viterbo exhibition (Architettura etrusca nel Viterbese 1986; cf. above, section I:1). P.G. Gierow describes the topographical setting of the site, C. Nylander the urbanistic features, the house plans and - together with B. Blomé - the wall constructions. I. Pohl gives a historical outline of the site.

A short, general account of the results is presented by C. Nylander (1986), while I.
Pohl (1987) discusses the evidence for food and drink at the site.

\section{San Simone (Simonov Zaliv)}

In 1986, Swedish archaeologists started excavations of a Roman villa (Imperial times) at San Simone in Slovenia (G. Labud 1989a, 1989b, 1990). A series of rooms with mosaic floors has been uncovered. From 1988 onwards, the project also included underwater investigations of the adjacent Roman harbour and its moles.

\section{Carthage}

The geodetic and cartographic survey of ancient Carthage initiated in 1979 (cf. SA 1976-1980:101) was continued in 1983 with the use of a new and better triangulation grid. A preliminary account of the work is presented by C.-G. Styrenius et al. (1986).

\section{ITALY BEFORE ROMAN DOMINATION}

\section{The Bronze and Iron Ages}

B.S. Frizell (1987, 1989) continues her studies on dry masonry domes in the Mediterranean area (cf. SA 1981-1985: 177f.). The author now widens her interest from Mycenaean tholos tombs, focussing instead upon the Sardinian nuraghi. Using comparative evidence from modern dome building in Apulian trulli, she challenges the orthodox view that these constructions should be considered "false" domes, emphasizing the fundamental technical differences between domes and arches. The author also questions diffusionist views of the nuraghi being influenced by Mycenaean forerunners, advocating instead autonomous developments of both nuragic domes and early Etruscan tholos tombs.

In 1989, Frizell organized an international symposium on "Arte militare e architettura nuragica" at the Swedish Institute in Rome, a popular account of which has al- 
ready appeared (Frizell 1990).

G. Labud (1986), in a popular paper, presented the Bronze and Iron Age Castellieri culture of Istria. K. Berggren (1990) gives a popular account of her views on two find categories from Central Italic, Early Iron Age graves: bronze "razors" and ceramic helmets, both of which she prefers to interpret as symbols of a moon goddess.

\section{Central Italy in the Archaic period}

The continuing interest of Swedish scholars in this field is well documented during our period of investigation. It is possible to distinguish two main trends of research: one concerning Etruscan vase-painting of the Archaic and Classical periods, the other an interest generated by the excavations of Acquarossa (cf. Section II:1) in Archaic architecture in general and architectural terracottas in particular. The field of vasepainting includes Etrusco-Corinthian (Ch. Wikander 1988b, 1989): two vases of the so-called "Pescia Romana Painter", now identified as the same individual as the earlier "Painter of the American Academy" preserved in Stockholm. Etruscan blackfigure vase painting is treated by $\mathrm{Ch}$. Scheffer (1986b) and I.E.M. Edlund (1986a). Both scholars are concerned in the analysis of what constitutes independent Etruscan elements in the black-figure industry, separating this from the Athenian tradition.

In the field of architecture, Ö. Wikander extended his work on the roof-tiles of Acquarossa (cf. Section II:1) to the early periods of tile-production both in Greece and Italy (Ö. Wikander 1990a) as well as to the functional reasons behind the transition from roofs covered with thatch to the tiled roof (Ö. Wikander 1988). Ch. Scheffer (1990) treats the possibility of Greek antecedents (on the Agora of Athens) to the particular form of colonnaded architecture demonstrated both by the Regia in Rome and Building $\mathrm{C}$ in the monumental area of Acquarossa (for an interpretation of an older buil- ding of Zone $\mathrm{F}$ as being of the same type, cf. Wikander \& Wikander 1990, Section II.1).

Apart from these two areas there are the iconographic interpretations of Archaic Etruscan art in general by G. Säflund (Säflund 1986a, 1989). The author brings a ritual interpretation (in particular the hieros gamos) to artifacts in a number of different media, ranging from ceramics to architectural terracottas.

The work of I.E.M. Edlund on the location of sanctuaries in Southern Italy and Etruria (cf. Section III:4) has also led to a short symposium contribution concerning the locations and finds of Etruscan healing cults (Edlund 1987b).

\section{Central Italy in the Classical and} Hellenistic periods

This field is dominated by the work of I.M.B. Wiman on Etruscan bronze mirrors. Three smaller studies (Wiman 1986a, 1986b, 1990a) precede her dissertation Malstria-Malena. Metals and motifs in Etruscan mirror crafts (Wiman 1990b). All these works centre around the establishment of a correlation between "hard data" (i.e. metal analyses of different kinds) and "soft data" (stylistic analysis). By a combination of these factors the author attempts to isolate local mirror workshops formerly only tentatively (or not at all) separated.

Votive figurines in Italian sanctuaries are briefly treated by B.M. Fridh-Haneson (1987) and C. Beer (1987), both on occasion of the Symposium Gifts to the Gods held in Uppsala in 1985. In Beer's case, the contribution is closely connected to her then ongoing work on the so-called "templeboys" of Cyprus; she treats statuettes of small nude children and discusses the interpretation of their possible function.

\section{The Greeks in Southern Italy and Sicily} The interest devoted to this area by Swedish scholars tends to concentrate on the 
areas of architecture, particularly religious architecture. A prime example of this is Edlund 1987c, a monographic study dealing with the location of sanctuaries in the Greek part of Italy compared to the situation in Etruria. The study treats mainly archaeological, but also textual, evidence for such sanctuaries. The main emphasis is placed on a distinction between rural, extra-urban and urban sanctuaries; the different forms of religious tradition and/or political domination of the sanctuaries is subjected to analysis by the author. Ch. Wikander (1986) re-examines Archaic architectural terracottas from Sicily in an attempt to make this published but widely scattered material more easily accessible to further scholarship. In Ch. Wikander 1990, the sima-form of an early sanctuary at Locri is advanced as a possible model for the Archaic sima of the Artemision on Corfu. Finally, L. Karlsson (1989) contributes a preparatory study for his dissertation work on Sicilian fortifications.

\section{ROMAN ITALY}

\section{The Late Republic and the Early Empire} Several articles on Roman art and artifacts have already been discussed (above, sections I:1-2). Moreover, B. Mattsson (1990) tries to analyse Roman tombstones "with ascia figure and/or the formula sub ascia dedicare", most of which derive from the II and III centuries A.C. The significance of the adze symbol has been the subject of much discussion, but Mattsson bases his study on a much larger selection of tombstones than anyone before him. His catalogue contains 1194 entries presented according to the volumes of the Corpus Inscriptionum Latinarum. Examples are known from most provinces west of the central Balkans, but no less than $80 \%$ derive from Italy, Dalmatia and southern Gaul. Gallia Lugdunensis alone represented by $1 / 3$ of the material. In his short, concluding chapters, the author discusses various theories concerning the meaning of the symbol, supporting the one that explains it by the tomb being dedicated before being finished.

A.-M. Leander Touati has produced a major work on one of the most central monuments of Roman Imperial sculpture, the Trajanic frieze plaques incorporated in the Arch of Constantine in Rome (Leander Touati 1987; cf. also above, Section I:1). This study spans a wide spectrum, from detailed studies of e.g. the military equipment depicted in the frieze, to an all-embracing attempt at interpretating the message intended for the Roman viewers. This last ambition is firmly grounded in semiotic theory, and Leander Touati makes a thorough effort to put a modern theoretical approach at work to further our understanding of ancient intentions, so clouded for us by the lack of source material in sufficient quantities.

Two short articles, one by the abovementioned author (Leander Touati 1988a) and the other by C. Nylander (1988) treat Roman sculpture in relation to the environmental problem, particularly at Rome. Both were occasioned by the determined efforts of the archaeological authorities to clean and restore Imperial monuments, and the disastrous effect of pollution observable in the course of this work.

Studies on Roman architecture are scarce. I. Pohl's work at the Piazzale delle Corporazioni at Ostia and G. Labud's on a Roman villa at San Simone, Istria, have been mentioned above (sections 1:5, 8). In a preparatory study for his dissertation (1990b), Labud also outlines the evidence for agricultural production and mercantile activities in Roman Istria. The same issues, including the archaeological investigations at San Simone, are the subject of two popular papers by the author $(1988,1990 \mathrm{c})$.

H. Erkell (1987) continues his studies of Roman topography based on a close reading 
of Varro's De lingua Latina. Among other things, he proposes a new explanation for the use of the word collis (not mons) to designate the Viminal and the Quirinal, and supports the theory that the cult at the Ara Maxima was originallly devoted to the Phoenician Melqart. The same author (1990) and $\AA$. Fridh $(1987,1990)$ are also involved in a polemic discussion concerning the extension of the Pagus Succusanus and the relationship between Esquiliae and the mons Esquilinus.

Ö. Wikander (1986c) presents new tendencies in modern research on ancient technology and also discusses the role of engineers and craftsmen in the diffusion of technical knowledge in Antiquity (1986d). I. Granstam (1990) gives a popular account of the technical aspects of Roman vaulting.

\section{Late Antiquity}

This period continues to attract little interest from Swedish scholars. Half a dozen papers treat either architectural issues or the use of water-power.

\section{REFERENCES}

Architettura etrusca nel Viterbese. Ricerche svedesi a San Giovenale e Acquarossa 19501986 (Catalogue of the exhibition at Viterbo, Museo Archeologico Nazionale - Rocca Albornoz, Viterbo 1986, eds. Paavo Roos \& Örjan Wikander) (with contributions by B. Blomé, P.G. Gierow, C. Nylander, C.B. Persson, I. Pohl, E. Rystedt, Ch. Scheffer, M. Strandberg Olofsson, A. Vidén, L. Wendt, Ch. Wikander \& Ö. Wikander), Roma 1986.

Beer, C. 1987. Comparative votive religion: the evidence of children in Cyprus, Greece and Etruria. In:Gifts to the Gods. Proceedings of the Uppsala Symposium 1985, eds. T. Linders \& G. Nordquist (Boreas 15). Uppsala. 21-29.

Berggren, K. 1990a. Mångudinnans hjälm, Medusa 11:3. 23-30.

- 1990b. The Capestrano warrior and the Numana
R. Billig (1990) contributes to our knowledge of urban architecture by comparing pictorial representations and archaeological finds of various building elements: entrance porches (prothyra), towers used for dwelling, semicircular porticoed "sigma" forecourts, etc. Ö. Wikander (1989) also uses ancient representations to study the development of tiled roofs from the early Empire to the $\mathrm{XV}$ century.

P. Roos (1990) discusses epigraphic and archaeological evidence for water-mills in Asia Minor and in another paper (1986) examines and corrects a "long-lived mistake" concerning the slope of the large mill establishment at Barbegal in southern France. Ö. Wikander (1989) tries to establish the precise location of the Ruwer saw-mills mentioned by Ausonius in the Mosella, explaining the reasons for the poet's interest in them. The same author, in a conference paper (1990), presents his current views of the diffusion of water-mills and technical progress in general in the Roman Empire.

head. A structuralist semiotic interpretation. Opuscula Romana 18. 23-36.

Billig, R. 1990. Bilder und Bodenfunde. Kleine Beiträge zur Kenntnis der spätantiken Stadt. Opuscula Romana 18. 37-60.

Carlén-Nilsson, C. 1986. Mytologiska miniatyrer. In: Kulturens Arrsbok 1986. Lund. 72-76.

Edlund, I.E.M. 1986a. Native and foreign elements in the artistic fauna of black-figure vase-painting in Central Italy. In: Italian Iron Age artefacts in the Brithish Museum. Papers of the sixth British Museum colloquium, London 10-11 December 1982, ed. J. Swadling. London. 431-434.

- 1986b. Scavi nella zona di Metaponto. Sant' Angelo Vecchio. Bollettino d'Arte 71, nr. 3940. 119-122.

- 1987a. The sacred geography of southern Italy in Lycophron's Alexandra. Opuscula Romana 
16. 43-49.

- 1987b. Mens sana in corpore sano: healing cults as a political factor in Etruscan religion. In: Gifts to the Gods. Proceedings of the Uppsala Symposium 1985, eds. T. Linders \& G. Nordquist (Boreas 15). Uppsala. 51-56.

- 1987c. The gods and the place. Location and function of sanctuaries in the countryside of Etruria and Magna Graecia (700-400 B.C) (Skrifter utgivna av Svenska Institutet i Rom, - 40, 43). Stockholm.

- 1988. Classical themes in South Italian votive terracottas of the fifth and fourth centuries B.C. Continuity and development in cults and iconography. Praktika tou XII Dieqnouß sunedriou klasikh $\beta$ arcaiologiaß, 2. 237-242.

Edlund-Berry, I.E.M. 1989a. Four terracotta heads from Poggio Civitate (Murlo). Towards a definition of the Murlo style. Opuscula Romana 17. 21-32.

- 1989b. R.D. DePuma, I.E.M. Edlund-Berry \& L.S. Merritt. Kyle Meredith Phillips, Jr., 19341988. AJA 93. 239-240.

Erkell, H. 1987. Varroniana III. Studi topografici. - Il culto all'Ara Maxima. Varro, De lingua latina V \$§51-54 e VI \$ 54. Opuscula Romana 16. 51-57.

- 1990. From the Esquiliae to the Esquiline. Eranos 88. 125-137.

Fridh, §. 1987. Three notes on Roman toponomy and topography. Eranos 85. 115-133.

- 1990. Esquiliae, Fagutal, and Subura once again. Eranos 88. 139-161.

Fridh-Haneson, B.-M. 1987. Votive terracottas from Italy. Types and problems. In: Gifts to the Gods. Proceedings of the Uppsala Symposium 1985, eds. T. Linders \& G. Nordquist (Boreas 15), Uppsala. 67-75.

Granstam, Ingrid 1990. Romerska bågar. Om antik teknik i allmänhet och Pont du Gard i synnerhet. Romhorisont. 3-5.

Hellström, P. 1989. A Mithraic charioteer? Medelhavsmuseet Bulletin 24. 35-48.

Karlsson, L. 1989. Some notes on the fortifications of Greek Sicily. Opuscula Romana 17. $77-89$.

Labud, G. 1986. Castellierikulturen i Istrien. Medusa 7:2.14-19.

- 1988. Istrien och romarna. Medusa 9:1. 23-26.

- 1989a. Nuovi ritrovamenti architettonici romani a San Simone presso Isola (Campagne di scavo 1986-1989). Atti e memorie della
Società Istriana di arechologia e storia patria. 7-17.

- 1989b. Il territorio del sito archeologico di San Simone d'Isola. Opuscula Romana 17. 91-95

- 1990a. Rapporto preliminare sulle campagne di scavo del 1988 e del 1989 a San Simone (Simonov Zaliv) presso Isola. Opuscula Romana 18. 213-215.

- 1990b. Società ed economia: Studi sull'attività agraria e commerciale dell'Istria in età romana. Arheoloski Vestnik 41. 257-266.

- 1990c. Det romerska Istrien. Sfinx 1990:2.3942.

Leander Touati, A.-M. 1986. Antikens ansikte. Medusa 7:3. 31f.

- 1987. The great Trajanic frieze. The study of a monument and of the mechanism of message transmission in Roman art (Skrifter utgivna av Svenska Institutet i Rom, - 40, 45). 1987.

- 1988a. Monument i närkontakt. Romhorisont 15. 3-8.

- 1988b. Gustaf III:s antiker i marmor. Valör 10. 212.

- 1990. Commodus wearing the lion skin. A "modern" portrait in Stockholm. Opuscula Romana 18. 115-129.

Mattsson, B. 1990. The ascia symbol on Latin epitaphs (SIMA-Pocket Books 70). Göteborg.

Nylander, C. 1986. Attività archeologica nel Viterbese dell'Istituto Svedese di Studi Classici a Roma. In: Archeologia nella Tuscia II, Atti degli incontri di studi organizzati a Viterbo 1984 (Quaderno del Centro di Studio per l'Archeologia Etrusco-Italica, 13), Roma. 105-112.

- 1988. S.O.S. for ancient monuments. Archaeology July/August. 54-57, 74f.

Pålsson Hallager, B. 1986. De første grækerne i Italien. Sfinx 9. 35-39.

Prohászka, M. 1986. Fibulan - antikens dräktspänne. Medusa 7:4. 10-19.

Pohl, I. 1987a. San Giovenale. In: L'alimentazione nel mondo antico. Gli Etruschi (Exhibition Catalogue, Viterbo). Roma. 71-73.

- 1987b. Piazzale delle corporazioni, Portico ovest: saggi sotto i mosaici. In: M. Carta, I. Pohl \& F.Zevi, Ostia.LaTaberna dell' invidioso. Piazzale delle corporazioni, portico ovest. Saggi sotto imosaici (=NSc, ser. 8, 32, Suppl.). Roma. 
Roos, P. 1986. For the fiftieth anniversary of the excavation of the water-mill at Barbegal: a correction of a long-lived mistake. Revue Archéologique. 327-333.

- 1990. Zu antiken Wassermühle in Kleinasien. In: Festschrift für Jale Inan, Istanbul. 495499.

Rystedt, E. 1986a. Rystedt, E., Scheffer, Ch., Strandberg Olofsson, M., Wikander, Ch. \& Wikander, Ö. The Swedish excavations in southern Etruria. Ed. Ch. Scheffer. Stockholm.

- 1986b. Svensk-italiensk utställning i Viterbo. Medusa 7:3. 6f.

- 1990. Ricerca topografica intorno ad Acquarossa: relazione preliminare. Opuscula Romana 18. 215-219.

Säflund, G. 1986a. Hieros Gamos'-Motive in der etruskischen Sepulcralkunst. In: Iron Age artifacts in the British Museum. Papers of the 6th British Museum Classical Colloquium, ed. J. Swaddling, London. 471-478.

- 1986b. Fest på etruskiskt vis. Romhorisont, Etruskernummer. 14-17.

- 1989. Etrusker, vad menade ni egentligen? Etruskiskt bildspråk - symbol och mening (SIMA, Pocket-book 74). Göteborg.

Santillo Frizell, B. 1987. The true domes in Mycenaean and Nuragic architecture. In: Studies in Sardinian Archaeology III, Nuragic Sardinia and the Mycenaean world, ed. M.S. Balmuth (BAR International Series, 387). Oxford. 57-75.

- 1989. The autonomous development of dry masonry domes in the Mediterranean area. Some considerations. Opuscula Romana 17. 143-161.

- 1990. Vad tjänade nuragherna egentligen till? Romhorisont 19. 9 f.

Scheffer, Ch. 1986a. A Roman funerary relief with Talamones. Medelhavsmuseet Bulletin 21. 73-80.

1986b. Etruskerna är inte mest till sin fördel när de målar vaser. Romhorisont, Etruskernummer. 6-10.

- 1987a. Roman cinerary urns in Stockholm collections (Medelhavsmuseet, Memoir 6). Stockholm.

1987b. Acquarossa. In: L'alimentazione nel mondo antico. Gli Etruschi (Exhibition Catalogue, Viterbo). Roma. $75 \mathrm{f}$.

- 1987c. Forni e fornelli etruschi in età arcaica. Ibid. 97-105.
1990. "Domus Regiae" — a Greek tradition? Opuscula Atheniensia 18. 185-191.

Söderlind, M. 1988. Silenos' tre ansikten terrakottaskulptur från Gela. Medusa 9:4. 2-7.

Strandberg Olofsson, M. 1986. Permanent etruskisk utställning i Viterbo - en skiss i ord och bild. Romhorisont, Etruskernummer. 4f.

- 1990. On the reconstruction of the monumental area at Acquarossa. Opuscula Romana 17. 163-183.

Styrenius, C-G. Nilsson, K. A., Olson, A. \& Johansson, B. 1986. The Swedish Carthage excavations. Preliminary geodetic and cartographic studies. Medelhavsmuseet Bulletin 21. 81-91.

Wikander, Ch. 1986. Sicilian architectural terracottas. A reappraisal (Skrifter utgivna av Svenska Institutet i Rom, $\left.-8^{\circ}, 15\right)$. Stockholm.

- 1987. Etruskerna i Malmö. Medusa 8:3. 8f.

- 1988a. Acquarossa I, The painted architectural terracottas, Part 2, Typological and decorative analysis (Skrifter utgivna av Svenska Institutet i Rom, - $\left.4^{\circ}, 38: 1: 2\right)$. Stockholm.

- 1988b. The Pescia Romana Painter in Stockholm. Medelhavsmuseet Bulletin 23. 33-40.

-1989. Two names - one hand. A new alabastron by the Pescia Romana Painter. Medelhavsmuseet Bulletin 24. 13-18.

- 1990. The Artemision sima and its possible antecedents. In: Proceedings of the First international conference on Archaic Greek architectural terracottas $\quad(=$ Hesperia 59:1), ed. N.A. Winter. Athens. 275-283.

Wikander, Ch. \& Wikander, Ö. 1987a. Etruskerna. Malmö Museer 28.9-15.11 1987 (Katalog nr. 356 = Malmö Museers Årsbok 1986-87), Malmö.

- 1987b. The Etruscological collections of Olof August Danielsson II. Medelhavsmuseet Bulletin $22.45-48$.

- 1990. The early monumental complex at Acquarossa. A preliminary report. Opuscula Romana 18. 189-205.

Wikander, Ch., Wikander, Ö. \& Colonna, G. 1987. An Etruscan inscription from Acquarossa. Opuscula Romana 16. 147f.

Wikander, Ö. 1986a. Acquarossa VI. The rooftiles. Part 1. Catalogue and architectural context (Skrifter utgivna av Svenska Institutet i Rom, - 40, 38:6:1). Stockholm.

1986b. Olof August Danielsson och den etruskiska filologien. Ett förbisett hundra- 
årsminne. Romhorisont, Etruskernummer. 1113.

- 1986c. Framsteg eller stagnation? Nyare strömningar i antik teknikhistoria. Polhem 1986:3. 145-164.

- 1986d. Vetenskapsmän och ingenjörer. Om spridningen av kunskap i den antika världen. Daedalus — Tekniska Museets Årsbok 1986. Stockholm.16-27.

- 1987. A silenus head in Stockholm. Medelhavsmuseet Bulletin 22. 40-44.

- 1988. Ancient roof-tiles - use and function. Opuscula Atheniensia 17. 203-216.

- 1989a. Ausonius' saw-mills - once more. Opuscula Romana 17. 185-190.

- 1989b. Roman and mediaeval tile-roofs. Evidence from representations. Opuscula Romana 17. 191-203.

- 1989c. A Roman bronze lamp stand in Stockholm, Medelhavsmuseet Bulletin 24. 31-34.

- 1990a. Archaic roof-tiles: The first generations. In: Proceedings of the First international conference on Archaic Greek architectural terracottas (=Hesperia 59:1), ed. N.A. Winter. Athens. 285-290.

- 1990b. Water-power and technical progress in classical antiquity. In: Ancient technology (Finnish Institute at Athens, Symposium held 30.3 - 4.4 1987), Helsinki. 68-84.

Wiman, I.M.B. 1986a. Bronsanalyser av speglar - en väg mot ökad kunskap om antikens Etrurien. Romhorisont, Etruskernummer. 20-24.

- 1986b. Style, chemistry and multivariate statistics in the classification of some Etruscan mirrors. Medelhavsmuseet Bulletin 21. 49-72.

- 1986c. En etruskisk spegel på Kulturen. In: Kulturens Årsbok 1986, Lund. 88-93.

- 1989. Indications of consistency between physical data and ornamental decoration within two groups of Etruscan mirrors. Opuscula Romana 17. 213-224.

- 1990. Malstria-Malena. Metals and motifs in Etruscan mirror craft (SIMA 91). Göteborg.

Winbladh, M.-L. 1988. Two Roman mosaic fragments. Medelhavsmuseet Bulletin 23. 41-48. 